\title{
Islam Without Europa Traditions of Reform in Eighteenth-Century Islamic Thought
}

\author{
Arş. Gör. Yusuf ÖTENKAYA*
}

Islam Without Europa Traditions of Reform in Eighteenth-Century Islamic Thought

Ahmad S. Dallal

New York: The University of North Carolina Press, 2018, s.440

ISBN:9781469641409

\section{$\S \S \S$}

Georgetown Üniversitesi öğretim üyelerinden olan Ahmad Dallal'ın çalışmaları, erken modern ve modern dönem İslâm düşüncesi ve hareketleri üzerinde yoğunlaşmaktadır. Bunun yanında bilim tarihi, İslâmî diriliş düşüncesi ve İslâm hukukuyla da ilgilenmektedir. Müellif, The Islam Without Europa isimli çalışmasının giriş bölümünde pek çok problemli gelişmelere rağmen 18.yy düşünürlerinin geleceğe umutla baktıklarını belirtmiştir. Onlar öncekilere nispetle sonraki Müslümanların, yani kendilerinin üstünlüğünü açıkça iddia ediyorlardı. Onlar her şeyden evvel fıkıh ekollerini aşan, mezhepçiliği yok eden ve İslâm'ın nasıl tanımlanacağı noktasında birbirleriyle fikir alışverişinde bulunan, müşterek açıklamalar yapmaya çalışan kimseler olduklarını söylüyorlardı (s.11).Daha sonrasında oryantal anlatımın Doğulu toplumlarda adeta algı haline gelip içselleştirilen; duraklama, gerileme, yıkılış gibi kavramları müellif hiç zikretmemektedir. Bunun yerine entelektüel gelişmeler başta olmak üzere toplumsal ve siyasal bahislere yer vermektedir. Bu nedenle eseri okurken bir geleneğin nasıl devam ettirilmeye çalışıldığını müşahede edersiniz.

Müellif merkezî devletlerin hızla çözülmeye başlamasını, 18.yüzyııın alamet-i farikası olarak görmektedir. Nitekim 1718 yılında Osmanlılar, Balkanların bir bölümünü teslim etmeye zorlayan bir anlaşma imzalamıştır. Avrupa'ya nispetle bu askeri gücün zayıflamasıyla Osmanlı devleti, Avrupalı rakiplerinin uygulamalarından bazılarını edinerek bürokrasi ve askerî alanda reformlar yapmışlardır. Hemen hemen aynı dönemlerde, 1739'da İran'ın yeni hükümdarı Nadir Şah, Delhi'yi yağmaladı ve hemen ardından iyice zayıflayan Moğollara son verdi. Dallal'a göre bu merkezileşmiş ve merkezileşmekte olan devletlerin zayıflaması, Müslüman dünyayı geri döndürülemez bir duraklamaya sokmamıştı. Söz gelimi Osmanlı devleti'nde canlı ve diri ekonomileriyle otonom yerel güçler; Lübnan dağları, Suriye, Irak, Filistin ve Mısır gibi yerlerde temayüz etmişlerdi. Bu nedenle hâlâ 18.yy kültürü konusunda nasıl bir vaziyet olduğu noktasındaki bilgilerimiz sınırlı ya da hakikâtten oldukça uzaktır. İşte bu kitap, 18.yüzyılın sıradışı kültürel başarılarına odaklanmaktadır. Bunu yaparken Avrupa etkisinden bağımsız olarak geliştirilen İslâmî kültürel üretimin eğilimlerine odaklanılacaktır. Bu doğrultuda Batı Afrika'da

\footnotetext{
* Zonguldak Bülent Ecevit Üniversitesi, Tarih Bölümü, e-posta: yusufotenkaya@gmail.com, ORCID: 0000-0001-6721-4888
} 
Osman ibn Fûdî, Kuzey ve Sahra Afrika'sında Muhammed b. Senûsi'nin yaptıkları hareketlerin sosyal önemlerine ve reformlarının entelektüel değerlerine dikkatle bakıımıştır (s.13).

Geçmişi hatırlamak hiç de masumane ve objektif bir amaç/hedef değildir. Modernler de sıklıkla geçmiş kültürlerin enkazını, kalıntılarını topluyorlar ve günümüzde sosyal gerçekliklere, karanlıkta olan ya da tam olarak idrak edilemeyen şeyleri naklediyorlar. Bu anlayış, bu kitabın amacı değildir. Bu kitabın amacı, Müslüman dünyadaki modern öncesi bir dönemin entelektüel başarılarının kültürel ve sosyal anlamda ne denli etkili olduğunun vuzûha kavuşturulmasıdır. Bu kitabın hipotezi, 18.yy'ın bir çürüme ya da bozulmadan ziyade entelektüel canlılığın evresi olduğunu kanıtlayabilmektir. Bu nedenle bu çalışma büyük bir yanılgıyı telafi etmek için telif edilmiştir. Bu iddiaları ortaya koyabilmek için Müslüman ülkelerde yetişen âlimlerin eserlerine odaklanılmışıı. Bu âlimlerin ortak özelliği, çağlarının son derece ilerisinde olmaları, eserlerinin geniş çaplı olarak tüm dünyada otorite kabul edilmesi ve de kendi ülkelerinin çok çok ilerisinde olmalarıdır.

18.yy genel anlamda algılarla şekillendiği için "çürüme devri" olarak telakki edilmektedir. Bu düşünceye göre "Avrupa meydan okuması ve Avrupa'ya cevap verebilmek için İslâm dünyası bir dizi reform hareketlerine girdi" şeklinde bir değerlendirme hiç de sağlıklı değildir. Böyle bir kanı/algı hiç şüphesiz Mısırın Fransa tarafından işgal edilmesi neticesinde yorumlarda bulunan Abdurrahman el-Cebertî (1756-1825), Rifâa el-Tahtâvî (1801-1873) gibi isimlere büyük saygısızlık olur. Bu isimler, olayı şöyle yorumladılar: "Mısır ulusu için İslâmî rasyonaliteye geri dönmek..." Yani bu cümleden hareketle, mezkûr isimler kendi sahip oldukları miraslarında nelerin olduğunu gayet iyi biliyorlardı. Yani 19.yüzyılın sonlarında ve 20.yüzyılda Osmanlı coğrafyasında sıklıkla vurgulandığı gibi "İslâm terakkiye mânidir" şeklinde bir anlayışları bulunmuyordu. Ya da körü körüne "İslâm geri olduğu için Avrupa'ya dönülmesi ve onun taklit edilmesi gerekir" gibi bir anlayışları da yoktu. Bazı açıklarının farkındaydılar ve bu açıkların tedavisini de İslâm'da görüyorlardı (s.14). Ancak hemen belirtelim ki, çalışmada 18.yy dâhilinde herhangi bir coğrafyaya ya da spesifik bir bölge/ülkeye odaklanılmadığı için okuyucu genel bir çıkarım yapmak durumunda kalmaktadır.

18.yy üzerinde çalışan tarihçilerin büyük bir bölümü, özellikle de oryantal zihniyetin ürettiği paradigmanın etkisinde kalan araştırmacılar, ne yazık ki bu dönemdeki durağanlığa dikkat çekmek için Vehhâbî hareketine odaklanmaktadırlar. Ancak hemen belirtelim ki bu dönemde ortaya çıkan Vehhâbîlik'in politik ve entelektüel faaliyetlerle bir ilgisi olmayıp, daha ziyade mezhepsel anlamda çatışmalar içerisine girdikleri tespit edilmiştir. Ancak bu araştırmacılar bununla da kalmayıp 11 Eylül 2001 saldırılarına dikkat çekip, bu radikal hareketlerin arkasında 18.yy'da ortaya çıkan Vehhâbîlik'inolduğunu belirtmişlerdir. Kaldı ki bu dönemde ortaya çıkarılan Vehhâbîlik, doğrudan petrol ile ilişkili olup İngiliz tesiri altında kurulmuştur. İngilizlerin yoğun desteği altında, bölgesel boşluklardan da istifade edip hâkimiyet alanlarını genişletmeyi başarmışlardır. Gerçekten de Avrupa etkisi nedeniyle Vehhâbîlik bir taraftan hızla yükselirken, öte yandan da koskoca bir 18.yüzyıl, oldukça zengin olmasına rağmen kötü bir nam salmış, tabir caizse çöküş devri olarak anılmıştır. Dolayısıyla ne Vehhâbîlik'in ne de çöküş kavramının 18.yy'daki Müslüman entelektüel hayatıyla bir ilgisi vardır (s. 15).

18.yy'ın revizyonist anlatımları ise Vehhâbîlik yerine, gerilemenin ya da çökmenin alâmeti olarak Sufizm, aşırı ruhaniyetçilik, ya da sosyo-ahlâki açıdan ideal insan tipi yetiştirmek üzere kurulu hadis külliyatlarının üzerinde durmuşlardır. Bu anlatım da tıpkı Vehhâbîlik de olduğu gibi konuyu entelektüel zeminden Sufizm ya da hadis üzerindeki yazılara çevirmiştir. Müellife göre bu ve benzeri düşünceler derhal terk edilmelidir. Kültür tarihi ile entelektüel tarih aynı kategoride değerlendirilmemelidir. Yine hakeza politik ekonomi tarihi de entelektüel tarihle aynı kategoriye koyulmamalıdır. Yine kendimize gelebilmemiz açısından öncelikle kültür dünyamızın bilgileri ya 
da fikirlerinin oldukça fakir/yoksul olduğu noktasında bizlere yerleştirilen algılardan tamamen kurtulup somut anlamda metinlerimizi, özellikle de 18.yy'daki üretimlerimizi incelememiz gerekmektedir (s. 16). Yine de 18.yy gerileme, çöküş anlatımlarının yaygın olmasının tek nedeni, önerilen revizyonist açıklamaların zayıfıklarıdır. 18.yy'da nasıl bir üretim gerçekleştirdiğimizi somut örnekleriyle gördüğümüz an bu husustaki sorunu çözebiliriz.

A. Dallal'ın her şeyden evvel çöküş tezini yok etmek için "ictihâd" meselesine eğildiği görülmektedir. İctihâd yani İslâmi reformlar yapma becerisine odaklanmıştır. Bu amaçla "ictihâd kapısı kapanmıştır" şeklindeki algıları değiştirmiş, bunun İslâm dünyasında kabul edilmediğini hatta şiddetle eleştirildiğini izah etmiştir. Ancak belli dönemlerde böyle bir anlayışın yerleştirildiğini de söylemiştir. İctihâd denilince akıllara fıkıh kuralları gelebilir fakat ictihâd 18.yy'da değişikliğe uğrayarak müelliflerin büyük projelerinin karşılığı olarak telakki edilmiştir. Bu anlamda söz konusu problemlere cevap veren bir mühendis, "müctehid" dersek yanılmış olmayız. Ancak müctehid olarak kendisini iddia eden "özgür düşünceli bireylerin" kendi toplumları tarafından kabul edilmediğine şahit oluyoruz. Aynı zamanda o toplumdakilerin müctehid olarak kendini gören insanlara türlü işkencelerde, eziyetlerde bulunduğunu görüyoruz. Söz gelimi Muhammed b. İsmail el-Âmir eş-Şan'anî (1688-1769) bunlardan biridir. Yemen'de kendi toplumu bile "müctehid" lafzına çok kızıp Şan'anî̀yi tekfir etmiştir (s. 17-18).

Müellif İnancın Sınırları şeklinde adlandırdığı birinci bölümdegenel olarak 18.yy düşünürlerine göre sorununun temezhüp olduğunu ifade etmiştir. Yani farklı fıkıh ekolleri arasındaki anlaşmazlıklar, körü körüne bağlanma ve karşıdakileri reddetme (tekfir)anlayışının büyük bir sosyal kriz haline geldiğini belirtmiştir. Nitekim bilindiği üzere Muhammed b. Abdülvehhâb'ın öğretilerinin büyük bir bölümünde "tekfir" geleneği bulunmaktadır. Dolayısıyla buna istinat eden oryantalistler, Vehhâbî öğretileri eleştirmeye, Müslümanların entelektüel anlamda zayıf olduğunu ifade etmeye başlamışlardır. Nitekim modern Müslüman siyasi, ekonomik ve sosyal tarihinin araştırmacıları arasından Albert Hourani, Arabic Thought in the Liberal Age 1798-1939 isimli eserinde bu dönemde İslâm dünyasında yetişen âlimlerin yüksek bir beceriye sahip olmadıklarını belirterek, onların genel anlamda toplumlarının ihtiyaçlarına cevap verebilmek ve Avrupa meydan okumasının karşısında faaliyet gösterebilmek için bazı modern Avrupa fikir ve kurumlarını benimsediklerini anlatmıştır. Müellif buna verdiği cevapta sosyal ve politik hadiselerle ilişkili olan mezhepsel anlayışların, genel bir değerlendirme aracı haline getirilmesine karşı çıkarak, Vehhâbîlerin kesinlikle entelektüel anlamda düşünülemeyeceğini, dolayısıyla da onların İslâm entelektüel tarihini lekeleyemeyeceğini vurgulamıştır (s. 26-27).

Müellifin ele aldığı şekliyle Muhammed ibn Abdülvehhâb diğer 18.yy düşünürlerinin ilgi ve kaygılarının hiç birisini paylaşmamıştır. Onun düşmanları Müslümanlara eziyet eden tiranlar değil, Tanrı hakkında yanlış inançlar savunan Müslümanlardı. Böyle bir anlayış politikaya alternatif üretememesine neden olmuştur. Onun ideolojisi bireysel Müslümanların inançlarına hoşgörüsüz davranmaktan ibaretti. Tek Tanrı'dan fazla Tanrı'ya inanmak, onun tenkit ettiği en önemli hususlar arasındaydı. Onun anlayışında şirk; türbe ziyaretleri yapmak, ölülerden medet ummak anlamına gelmektedir. Tevhid kavramıyla kuşanan İbn Abdülvehhab pratikte seyri değiştirmeye başladı. $O$, $\mathrm{Hz}$. Peygamber'in vefat ettiğindeki duruma dikkat çekerek, Ebû Bekir'e yapılan isyanın, Allah'a inanmamakla, Hz. Peygamber'i tanımamakla bir ilgisinin olmadığını, ancak sadece zekat vermekten imtina etmelerini hatırlatarak kendi zamanındaki müşriklerle bir bağ kurmuştur (s. 30). Ona göre kendi zamanındaki şirk, cahiliye dönemindekinden daha çetindir. Cahiliye döneminde insanlar açıktan Allah'ı reddediyorlardı. Allah'a karşı samimi bir inanç beslemediklerini zaten söylüyorlardı. Ancak bizim dönemimizdeki şirk ise gizli yapılan şirk olduğu için daha tehlikelidir. İslâm kâfirlerine karşı Vehhâbî savaşı sadece meşru değil, aynı zamanda "doğru inanç" hususunda ona alternatif değer taşımaktadır. 
Birinci bölümün alt başlıklarından olan eş-Şan'ani'nin Vehhâbîliğe karşı çıkması hususunda ise Şan'ani'nin Yemen'in en önemli müctehidleri arasında olduğu bilgisi verilmiştir. Onun müctehidlik iddiası özel bir ekole bağlı olmayacağı anlamına geliyordu. Fıkhî meselelerde ve hususi durumlardaki faaliyetlerinde bağımsız bir tavır takınabilirdi. Bu bağımsızlığın en önemli sonuçlarından biri, Şan'ani'nin farklı fıkıh ekollerinin yerleşik kurallarından kurtulmasıydı. Bu fıkıh ekollerinin sembolik değeri ne olursa olsun dikkat edilmemeliydi. Herhangi bir fıkıh ekolüyle doğrudan bir bağı olmadığı için kendisini sınırlamaya çalışanları dikkate almadı. Aynı zamanda o, fıkıh ekolleriyle anlaşmadığı durumlarda açıkça eleştirilerde bulundu ve onların kurallarını ciddi anlamda tenkit etti. Daha da önemlisi o, bazı Müslümanların birleşerek diğerlerini tecrit etmesini de şiddetle eleştirdi. Bu tutumları hasebiyle Yemen'de Zeydiler tarafından ölümle tehdit edilip türlü eziyetlere maruz kaldı. Camide vaaz vermekten men edildi ve iki ay kadar tutuklandı. Çünkü Zeydiler de diğer ekoller gibi eleştiriye tahammül edemiyorlardı (s. 37).

Şan'ani'nin öğretilerinde güçlü sosyal ve dinsel fikirler bulunuyordu. Devletle paralel çalışan dini kurumların eleştirisine ve devletin politik anlamda ciddi işler yapamaması noktasında idarecilerin eleştirisine, dolayısıyla da kendi ülkesindeki problemlere yönelik tespit odaklı ilerliyordu. Söz gelimiDivan adlı eserinde Şan'ani, Sanaa imamı el-Mansur Hüseyin'in, (ö.1748) kabilesinin elinde bir oyuncağa dönüştüğünü belirterek eleştiride bulunuyordu. Diğer taraftan Şan'ani, Yemen idarecilerini doğruluktan sapmakla suçlayıp, devletin yok oluşa sürüklendiğini ve tiranlığa doğru kaydığını belirterek eleştirilerde bulunuyordu. Onların kötü eylemleri o derece artmıştı ki, Şeytan'ı bile geride bırakmışlardı. Hatta Müslüman topraklarından daha fazla vergi alabilmek adına, onların bazılarının arazisini haraç arazisine tahvil ettiler. Yine Şan'ani, idarecilerden rüşvet alan fıkıh âlimlerini de suçlamıştır. Onlara karışmamaları, sessiz kalmaları ve eleştiride bulunmamaları hasebiyle, Şan'ani tarafından ciddi anlamda eleştiriye tâbi tutulmuşlardır. İbn Abdülvehhâb'ın yaptığı faaliyetlerin Müslümanların sorunlarına çözüm üretmekten çok, onlar arasındaki ayrılıkları körüklemeye yaradığını, onun entelektüel anlamda hiçbir şey bilmediğini belirtmiştir. Diğer taraftan dini anlamda İbn Abdülvehhâb'ın çok az şey bildiğini ve sadece konunun kısmî yönlerine dikkat kesildiğini belirterek onun doğru yolda olmadığını, hatalarının olduğunu, konuyu bütünsel açıdan değerlendirmediğini belirtmiştir. Ardından kâfirliğin ikiye ayrıldığı bilgisini vererek, ilkinde insanlar şayet Allah'ı yalanlıyor, mezhebi inkâr ediyorsa açıkça kâfir olmuş olur ve öldürülmesi doğrudur. İkinci küfür ise kişinin ibadetlerini yerine getirmemesiyle alakalıdır ki, bu hususta doğrudan onlarla savaşılması, mallarının gasp edilmesi, kâfir ilan edilmesi doğru değildir. Daha önce söylenildiği gibi bu hususta İbn Abdülvehhab, Hz. Ebû Bekir'in zekat vermeyenlerle savaşmasını anlatmaktadır. Böyle bir durum kişinin dinden çıkmasına neden olamaz. Nitekim bu hususta $\mathrm{Hz}$. Ömer'in ciddi anlamda eleştirileri bulunmaktadır. Gerçekten de küfür ile dinden çıkma arasında ciddi farklar vardır. Dinden çıkanın cezası ölüm iken küfre düşenin böyle bir cezası yoktur. En azından bu konuda mezhepler arasında ciddi intilaflar bulunmaktadır (s. 38-40).

Birinci bölümün bir diğer alt başlığında İbn Fûdî'nin politik tekfir ve sosyal toleransı hakkında bilgi verilmektedir. Günümüzde Kuzey Nijerya'da Sokoto halifeliği'nin kurulmasında büyük çabalar sarf eden Osman ibn Fûdî'nin (1754-1817) yaptığı çalışmalar, müellif tarafından titizlikle incelenmiştir. Osman ibn Fûdî'nin cihadı, öncelikle yabancılardan ziyade kendi içerisindeki Müslümanlara yönelikti. Onların bidat ehli ve zındık temayüllü kimseler olduğunu belirtmiştir. Bu durum dolayısıyla Vehhâbîlik'le onlar arasında bir ilişki bulunuyordu. İbn Fûdî'nin yaptığı açıklamalara göre Müslümanların bozulmasının ve çürümesinin belli başlı sebepleri arasında erkeklerin dört kadından fazlasıyla evlenip hukuku inmal etmeleri, mirasın en güçlü vâris tarafından gasp edilmesi, ticari yaptırımları ihlal etmeleri, ahlâki zayıflık ve çürümenin hâkim olması şeklindeydi. İbn Fûdî'nin çıkardığı netice, Müslümanların genel anlamda hem özel hem de genel hayatlarında kâfirlerin geleneklerini benimsemeleriydi ki, bu durum toplumun felaketi 
anlamına geliyordu (s.44).Buradan anladığımız kadarıyla İbn Fûdî'ye göre toplumun küfre düşmesinin sebebi toplumsal tabanlıydı. İbn Abdülvehhab'daki gibi İbn Fûdî için mezhep başlı başına amaç değil, sosyal reform için bir araçtı. $O$, insanları İslâm'ın temelleri üzerine dayanmak sûretiyle kurtuluşa davet ediyordu. Bunun yanında İslâmi kökene ait olmayan ne kadar gelenek, kuruluş varsa, hepsinden sıyrılmak gerektiğini açıkça belirtiyordu. Günahlardan dolayı kişinin kâfir ilan edilmesine karşı çıkıp, bunu değerlendirecek mekanizma olarak kendilerini görmemiştir. İbn Fûdî'ye göre sorun ancak ve ancak İslâmî normlara tekrar dönülerek halledilebilir. Meşru olmayan, kanunsuz olan, İslâm'la taban tabana zıt olan ne kadar anlayış varsa hepsinden uzaklaşılmalıdır. İdareciler kesinlikle Müslüman kardeşlerine karşı kâfirlerle anlaşma içerisinde olmamalıdır. Şayet imkanları varsa, o vakit onlara karşı cihad etmeleri gerekmektedir. Kâfir bir diyardan göç etmeyen bir Müslümanın, onlara ait olmayı tercih etmesi zorunludur.

Burada gördüğümüz üzere İbn Fûdî, politik tekfirle bireysel tekfir arasındaki ayrımı iyi tespit etmiştir. Bu anlamda bir Müslümanın malları, eşleri, çocukları gibi şahsa ait şeylerin gasp edilmesine karşı çıkmıştır. Politik tekfir ise cihad için gerekli olup hatta onun ön şartıydı. Bu konuda tolerans sağlamak mümkün değildi. Nitekim cihad, toplumun yanısıra bireysel anlamda Müslümanların çıkarlarına hizmet etmekteydi. Bu nedenle umumun maslahatı terk edilemeyeceğinden cihad da terk edilemezdi. Nitekim bu konuda toleransın sağlanması, İslâmî inanç hürriyeti ve teklifinin askıya alınması anlamına gelecektir. Bilindiği üzere işgal edilmiş bir beldede İslâm'ın teklifleri geçersiz olur. Dolayısıyla kişilerin üzerinde bulunan ibadetlerin vâcipliği düşer. Bir başka ifadeyle Müslüman olmanın ön şartı bağımsız olmaktır (s. 45).

Müellif Evrensel Vizyonun İctihâd ve Dinî Kökenleri başıklı ikinci bölümde amacının, 18.yy'da İslâm dünyasındaki devlet ve şahısların, karşılaştıkları problemleri çözmek için neler yaptıklarını teşhis etmek olduğunu belirtmiştir. Ancak içlerinden bazılarının ciddi problemleri de yok değildi. Söz gelimi bunlar daha önce de zikrettiğimiz üzere; tekfir, sosyal huzursuzluklar, taklit, entelektüel verimsizlik, türbe ziyaretleri ve onlardan birşeyler umma gibi yanlış inançlar ile birlikte hukuka (İslâm fıkhı) aykırı vergiler ve politik baskıları içeriyordu. Tercih krizleri genel anlamda "temezhüp" dediğimiz mezhepleşmeye, ayrılıklara yol açıyordu. Bu da bir hukuk ekolüne bağlıık, partizanlık anlamına geliyordu. Temezhüp ve ayrılıklar/bölünmeler neticesinde toplumsal hastalıklar baş gösteriyordu. Ancak hemen belirtelim ki genel anlamda 18.yy düşünürleri, bazı istisnalar hariç tutulursa tekfir anlayışını şiddetle eleştirmişlerdir. Söz gelimi Şevkânî'nin uyarısına bakalım: "Bil ki, temezhüp bilginin kutsallığının yok olmasına yol açtığı gibi, kan dökülmelerine neden olan bir iç savaşa, şeriatın teminatı altında olan her şeyin bozulabilir hale gelmesine neden olur (s.56). Bu noktada Vehhâbî hareketinin, diğer 18.yy düşünürleri ve akımlarıyla kıyaslandığında temezhüp hususunda ona en çok uyuşan bir yerde ya da konumda olduğunu söylememiz gerekiyor. Çünkü İbn Abdülvehhâb, Sufizm'e karşı çıkıp, salt Kur'an ve Sünnet'e dönmekten, geri kalan şeylerden ise arınılması gerektiğini söylüyordu. Bu da savaşları kaçınılmaz bir hale getiriyordu. Bu nedenle "köktenci akım" olarak anılmaktan da kurtulamadılar. Tıpkı Haricilerin yaptığını yapıp, bağlamdan kopuk bir anlayış geliştirdiler. Ayet ve hadisleri istedikleri gibi anlamaya, yorumlamaya başladılar.

18.yy düşünürlerini genel anlamda etkileyen şey, âlimlerin yaptıkları seyahatler neticesinde bilgi alışverişinde bulunmaları olmuştur. Bu seyahatler neticesinde entelektüel gelenekler diri tutuluyor, geçmişin tozlu numunesi hatırlanıyordu. Nitekim en fazla katkıda bulunan entelektüel faaliyetler, bölgesel gelenekler bağlamında ortaya çıkıyordu. Bu katkılar âlimler tarafından yapılıyordu. Onların fikirleri çok yönlüydü, kapsamlıydı. Geniş İslâmî mirasın çeşitli unsurlarına dayanıyordu. Ancak onlar birbirinden kopuk bir hal içerisinde olup, pan-İslamik bir karaktere dönüşemiyorlardı (s. 59). 
Osman ibn Fûdî'nin cihad sonrası devletinin can alıcı özelliği ve onun vazgeçilmez zorunluluğu medreselerin oluşturduğu ağ ve düşünce dünyası itibariyle Sokoto halifeliği boyunca idari merkezlerin yaygınlaşmasıydı. İbn Fûdî tarafından yürütülen cihad, eski toplumsal ve siyasal düzenin kalıntıları üzerine merkezî bir devletin kurulmasıyla birlikte pekçok yerde hangâhların kurulmasını sağlamıştı. Bu hangâhlar sayesinde Sanûsî, Libya ve ötesinde tam bir bağımısız ve çağdaş devlet kurabildi. Onun en büyük iddiası, Kur'an okunan ve şeriatın tatbik edildiği ülkelerde toplumsal ve ekonomik sorunların olmayacağıydı. Hakiki anlamda bu tatbik edilirse gerçekten de böyle olabilirdi. Ancak Sanûsî'nin Sufizm'den anladığı şey farklıydı. O, bir dizi reform uygulama yoluna gitti. Onun yaptığı teşkilâtlanmalar sadece Afrika coğrafyasında değil, önceki Sûfî anlayışlarında da bir dizi yeniliklere yol açmıştı. Dini doktrin ve uygulama ile politik, ekonomik ve toplumsal bağ kurulmuştu. Böylelikle Afrika'daki din anlayışının tarihsel gelişimi daha iyi anlaşılmış olabilir. Ancak hemen belirtelim ki, müellif burada özellikle Sanûsî'nin düşüncesinin şekillendiği Hicaz'da, Şevkânî'den etkilendiğini belirtmektedir. Fakat onun ictihâd ve hadis arasında nasıl bir bağ kurduğu hususu havada kalmıştır (s. 60-61).

Sanûsî'nin başlattığı Sûfî hangâh hareketi, Afrika'nın pekçok bölgesine yayılmış ve farklı isimlerde hayatiyet bulmuştur. Ticâniyye, Tarikât-i Muhammediyye bunlar arasındadır. Söz gelimi Ticâniyye'nin önde gelenlerinden Hacı Ömer et-Tall (ö.1864) Senegal bölgesinde bunun bir uzantısı olarak faaliyet gösterip, Fransa işgaline karşı direniş başlatmıştır. Paganlar arasında İslâm'ın yayılmasını hızlandırmıştır. Ancak onların reform çabaları, dışarıdan ciddi anlamda destekleri olmayıp Müslümanlar arasında tam anlamıyla birlik sağlanamadığından bölgesel karakterli kalmıştır (s. 61).

İkinci bölümün alt başlığı olan Entelektüel Güçlendirmenin Aracı Olarak İctihâd konusunda,18.yy Müslüman düşünürlerinin sorunlarını tespit ettiklerinde nasıl bir teori geliştirdikleri ayrıntılı bir şekilde anlatılmıştır. Tekfir, taklit ve temezhüp son derece problemli şeylerdir. Bunun dışında âdil olmayan idarecilere âlimlerin boyun eğmesi, kabilecilik, hukukun olmaması ve haksız vergiler gibi menfi haller problemlerin diğer halkasını oluşturmaktadır. Oryantal bakış açısının etkisinde kalan düşünürler ise İslâm'ı tamamen ya da kısmen modernlik, rasyonellik ve gelişmeyle tutarsız gördüler. Diğer taraftan 18.yy'ın diğer düşünürleri ise İslâm'ın sosyal düzen ve adalet hususunda doğrudan can alıcı bir öneme sahip olduğunu belirtmişlerdir. Onlar açısından problem, adaletsiz yöneticilerden kaynaklanıyordu. İslâmî alternatiflere dönerek bu problemlerin üstesinden gelinebilirdi. Bunun için diğer taraftan ictihâd mevzusunun önünün açılması gerekiyordu. İctihâd kapısının açılması belki de 18.yy'daki en önemli gelişmeler arasında yer alıyordu. Bu düşüncenin fiiliyata geçirilmesi Müslüman dünyasındaki entelektüel gelişmelere ivme kazandırıyordu (s. 64).

İctihâd, İslâm hukuku düzenlemeleri ve kurallarıyla ilişkili olma durumu şeklinde olup,teklifin doğal neticesidir. Eş-Şan'ani (ö.1768) Kur'an ve Sünnet'in ifadelerinin anlaşıması dışında harici bir şeye gerek duyulmayacağını iddia etmiştir. Ortalama bir anlayış kapasitesine ve bilincine sahip olan her Müslümanın, bu teklifi anlayabilecek düzeyde olduğunu belirtmiştir. Diğer taraftan ortalama bir Müslüman için mümkün olmayan ictihâd ise, Allah'ın insana bahşettiği şeylerin inkârı anlamına gelmektedir. İctihâdı inkâr etmek fıkhî sorumluluğu inkar etmeye, o da taklide yol açar. Esasında burada şöyle bir ilişki vardır: Her ictihâd taklit değildir, ancak her taklit bir ictihâdtır. Nitekim taklit, yaygınlaşıp taklithaline gelmeden evvel ilk ortaya atıldığında, Kur'an ve Sünnet dediğimiz delillere dayanıyor olması hasebiyle ictihâdtır. Dolayısıyla taklide kapılan her kişi esasında Kur'an ve Sünnet'den bir delile dayanıyordur. Bu nedenle de esasında aynı kanıtları, delilleri geliştirip yeni bir ictihâd çıkarabilecek durumdadır (s. 66).

A. Dallal, eserinin üçüncü bölümünde genel olarak Sûfizm'in 18.yy'da nasıl algılandığını ele alıp yöresel (vernacular) bağlamda bunu tartışmıştır. Bütün otoriter dini metinler ile ruhani bilgi 
ya da gnosis temalı metinlerin reddedilmesi gerektiği, 18.yy reformistlerinin tipik özelliğiydi. Geleneksel toplumlarda sûfîler ile kadılar otoritenin bir kanadını ele geçirmişken, diğer kanadında ise idareyi elinde tutan politik elitler bulunuyordu. Sûfîler, sürekli epistemik otorite hususunda kadılarla rekabet etmekteydi. Dahası sûfîler, kendi birikim ve tecrübelerinin, formal, legalistik (fıkha uygun) bilgiden daha üstün olduğunu söylüyorlardı. İşte 18.yy reformcuları, artık otorite hususunda her türlü arabuluculara karşı çıkıp, otoritenin seçkin kimselerin elinde olmasını eleştirdiler. Onlar için kişilerin hiçbir önemi bulunmuyordu. İster sûfî, ister kadı olsun farketmezdi. Toplumun bütün kısımları tarafından ictihâda doğrudan katıım, 18.yy reform projesinin en önemli özelliğini teşkil ediyordu. Bu reformculara göre ictihâd icra etmek, her Müslüman için zorunlu bir durumdur. Bu sayede ancak sûfîlerdeki hiyerarşik yapıya karşı çıkılabilir ve onların liderlerine sorgusuz olarak biat etmeye karşı çıkılabilirdi. Doğaüstü özelliklere haiz olan ve kusurdan azade olan sûfî liderlerini tanımaktan ziyade, Müslümanların esas görevi, kendi ictihâdlarını gerçekleştirmek ve bu dünyadaki konumlarını belirlemektir. Ancak sadece dışarıdan değil aynı zamanda sûfî grupların arasından da eleştiriler bulunmaktaydı. Onlar da Sûfizm'deki hiyerarşik yapıları kırmaya çalışıyorlardı. Dahası onlara göre Sufizm, doğaüstü dünyalarına çekilip, her türlü sosyal yüzleşmelerden kaçınmak değildi. Onların esas derdi, savundukları akımların gerçek dünyaya ne denli etki edip etmediği meselesiydi. Tüm bunları yaparken asıl önemli olan, İslâm'ın entelektüel mirasının bu olaydaki vasfının ya da konumunun ne denli öne çıkarıldığıydı (s. 86).

Üçüncü bölümün alt başlığı olan Şah Veliyullah Dihlevî ve Mistiklik'le Fıkhın Uzlaşısı adlı hususta, Şah Veliyullah'a göre akli, naklî ve vicdani bilimler bulunmaktadır. Bunların üçü de gerçek hayatta yer almaktadır. Akli-burhâni-istidlâlî ilimler genel anlamda kelâm disiplininde yer almaktadır. Naklî olanlara ise örneğin hadis ilmi verilebilir. Vicdani olanlara ise söz gelimi mistik/gnostik bilgi ya da sufizm diyebiliriz. Fiziğe tâbi olup dünya dâhilindeki meseleleri burhâni bilgilerimizle, tâbi olmayanları ise sûfî bilgi ve tecrübelerimizle çözebiliriz. Veliyullah'a göre, din hukukunun sessiz kaldığı meselelerin çözülmemesi mümkün değildir, yani çözülebilir ki bu da ancak gnostik/mistik/sûfî bilgiyle gerçekleşir. Ancak Veliyullah'ın buradaki amacı, Sufizm'in üstünlügünü vurgulamaktan ziyade, entelektüel iddiaları düzeyinde fıkıh ile Sûfîzm arasında bir farkın olmadığını gösterebilmektir. Muhammed b. Senûsî daha farklı düşünmektedir. Ona göre sûfîler Allah dostlarıdır. Pek çok hususta bilgi onlara Allah tarafından ilham edilebilir. Ancak sûfîlere bağışlanan böylesi bir bilgi her zaman mutlak anlamda sağlam/kesin değildir ve arayanlarını sapkınlığa götürebilir. Böylesi bir riske karşı yapılacak ilk iş, mistik tecrübeye karşı temkinli davranmak ve fıkhın formel zorunluluklarına uymaktır (s. 92-95).

Diğer bir alt başlık olan Şen'anî ve Şevkânînnin Vehhâbî Olmayan Sufizm Eleştirilerinde ise bu akımın aşııııkları ciddi anlamda eleştirilmiştir. Her iki âlim de Yemen'deki azizlerin türbe ziyaretlerini eleştiriyorlardı. Ancak onların eleştirileri Vehhâbîlik'den değil, doğrudan oradaki Zeydilerden ilham alıyordu. Şen'ani, sorgusuz bir şekilde imama tâbi olmayı doğru bulmuyordu ancak o imamların değerlerine, Vehhâbîler gibi dil uzatmıyordu. Şen'ani'ye göre sorgulanamaz olan tek otorite, Kur'an ve hadislerin metinsel kaynaklarında yer almaktadır. Yine Şen'ani'ye göre mistiklerin/sufilerin diğer Müslümanlara ayrıcalıklı olan üstünlükleri yoktur. Kerameti inkâr etmemesine rağmen inanç/iman ve takvanın önemine daha çok değer vermiştir. Bu düşünceleriyle İbrahim el-Kürdi'nin Kasdü's-sebil eserinde Tanrı'yı bilmenin sistematik akıl yürütmeyle mümkün olmadığını, O'nun sadece peygamberlik ve sûfîlikle bilinebileceği tezine karşı çıkmıştır (s. 96-97). Şen'ani'nin yolundan giden Şevkânî'ye göre de aslolan Kur'an ve Sünnet'de yer alanlar ile uyum içerisinde olabilmektir. Doğru inanış biçimi budur. Ölülerden medet ummak, bir ekole körü körüne bağlanmak, İslâm'ın canlılığına zarar veren hadiselerdir (s. 108).

Eserin dördüncü bölümünde muhaliflerin şeceresi ve bilgi politikaları hakkında ayrıntılı bilgiler verilmiştir. 18.yy'ın büyük reformcuları entelektüel projeleri hususunda radikal düşüncede 
olduklarını çok iyi biliyorlardı. Ancak onlar kendi farkındalıkları ile bir değişim arzuluyorlardı. Bir diğer ifadeyle değişim merkezleri Avrupa değil, bizatihi kendi deneyim ve tecrübeleriydi. Bu anlamda18.yy reformlarının en mühim payandalarını entelektüel çalışmalar oluşturuyordu. Tüm bunlarla birlikte sosyal ve politik değişimin olacağını, kendiliğinden oluşacağını iddia ediyorlardı (s. 123).

Müellif Siyasal Eylemin Çoklu Paradigmaları başlıklı alt bölümde ise tekfir geleneğinin eleştirilmesi, ictihâd anlayışının Müslüman kitleleri harekete geçiren ve aydınlanmasını sağlayan biçimde düşünülmesi ve bu bağlamda aracıların reddedilmesi, 18.yy reformistlerinin sosyal ve siyasal desteğinin/katılımının vurgulanıp kurulu güç yapılarının çökertilmesi gibi hususların, temel entelektüel faaliyetler olduğunu belirtmiştir. İbn Fûdî ve Senûsî tarafından şekillendirilen siyasal eylem paradigmalarının, çökertici/baskın ve devrimci olduğu vurgulanmıştır. İbn Fûdî, İslâmî olmayan sosyal ve politik düzen namına ne varsa hepsini toptan reddetmiştir. Böylesi âlimleri "politik küffar" olarak adlandırmıştır. Buna alternatif olarak İslâm'ın hâkim olduğu bir rejim yaratmaya çalışmıştır. Diğer taraftan es-Senûsî de yapılması gereken ilk iş olarak, Osmanlı devleti'nin egemen kontrolünden uzaklaşılması gerektiğini belirtmiştir (s. 124).

18.yy reformistleri; tırmanan adaletsizlikleri ve toplumlarındaki düzensizlikleri eleştiriyorlardı. İdarecilerin yasadışı vergiler koymaları, devletin güvenlik sağlama konusundaki başarısızlığı, Müslüman toprakların savunulamayışı bunlardan bazılarıdır. Söz gelimi Veliyullah bütün enerjisini, Müslüman devletin gücünün onarılmasına adamıştı. Bunu ise entelektüel araçlarla yapmayı planlıyordu. Senûsî ise devletin gücünün onarılmasıyla ilgilenmemiş, bunun yerine doğrudan ne kadar sosyal ve politik hastalık varsa tamamını eleştirmiştir. Bunların başında da türbe ziyaretleri geliyordu. Senûsî yaptığı bir konuşmada, en problemli şey olarak insanların herhangi bir kanıt olmaksızın vaizlerin uydurdukları şeyleri kabul etmelerinde gördüğünü söylemiştir. Diğer taraftan kabul edilemez ya da kınanması gereken eylemler hakkında şu bilgileri paylaşmıştır. Mecâbi olarak adlandııılan vergilerin yasaklanması dinde bulunmaktadır. Ancak bu tür vergiler dine rağmen yaygındır. Gerçekten de vergi tahsildarların elleri Mekke'ye kadar ulaşmıştır. Onlar, Mekke'ye hac farizasını yapmaya gidenlerden bu vergiyi alırlar. Bu hacılar Mekke'ye gelir gelmez bu kutsal şehirde kanunsuzlukların tümüne rastlarlar. Âlimler ve idareciler ise bu hukuksuzluklara ses çıkarmazlar. İşte onların sessizliği de bu hukuksuzlukları meşru hale getirmektedir. Diğer bir örnek ise yine kabe'dendir. Cahil ve yanlış yönlendirilen Çerkez idareciler, dört ekolden dört farkı ibadet mahalli kurmuşlardır. Bu durum ibadethanelere farklı dinlere aitmiş izlenimi vermektedir. Burada esas vurgulanması gereken husus, böylesi eylemlere karşı müctehidlerin (bağımsız âlimler) verdikleri kararlardır. Onların bağımsız kararlarının olmadığı yerde tiranlık vardır (s. 125-126).

Şen'ani, hadis külliyatları sayesinde idealize edilmiş insan tipleri oluşturmak istendiğini belirtmiştir. Söz gelimi türbe ziyaretleri konusunda, bunun sadece peygamber tarafından yapılıp diğer Müslümanlar tarafından yapılamayacağının açık bir ifadesi yoktur. Bu nedenle diğer Müslümanlar arasında da yaygınlık kazanmıştır. Diğer taraftan yüksek binalarda oturmak şeklinde kınanmalar vardır. Ancak bu doktrinler ve politikalar arasında korelasyon bulunmaktadır. Bu tür anlayışlar despot ve kralların sadece mülkü kendi tekellerinde görmelerinin neticesidir. Bunlar oluşturdukları anlayışları "algı" şeklinde halka işlerler (s.126).

Dördüncü bölümün bir diğer alt başlığı yeni entelektüel kimliğin geliştirilmesi hakkındadır. Müellife göremillet ya da ekol yanlısı kimlikler, her ne olursa olsun, ne kadar güçlü olurlarsa olsunlar entelektüel içerikten yoksun kalırlarsa, kolektif bilinç ürünü olarak ortaya çıkamazlar. Yani ortaya atılan teoriler bir anlamda İslâm ümmeti tarafından tam anlamıyla benimsenmez, sadece toplumun ya da ümmetin bir kısmınca kabul edilir. Buna somut örnek olarak Yemen âlimlerinin İslâm'ın erken döneminde çıkan teoloji tartışmalarına olan yaklaşımı verilebilir. Yemen 
reformistleri hem Eş'ariliği hem de Mutezile teolojisini reddediyordu. Çünkü her iki ekolün de yeterince entelektüel zemine sahip olmadıklarını düşünüyorlardı. Bunun yanında Allah'ın yaratmasında belirli bir hikmetin olduğunu kabul etmişlerdir. Bu anlayış onları Mu'tezile'ye yaklaştırsa da, Şevkânî; insan aklının her zaman bu hikmeti anlayamayacağını söyleyerek Mutezile'yi eleştirmiştir. Şevkânî'nin en önemli amacı, Müslümanları polarize eden, kutuplaştıran her türlü açıklamadan insanları kurtarmak, orta yolu bulabilmekti. Şevkânî'nin asıl amacı, İslâm tarihinin ana akımına Zeydileri sokabilmekti. Yani bilhassa entelektüel alanda Zeydilerin katkılarını kabul ettirebilmek, onlar açısından oldukça önemliydi. Şevkânî'nin iddiasına göre Yemen Zeydileri, Kur'an ve Sünnet hususunda bilgili olan çok sayıda âlime sahiptir. Onlar metinsel delillere bağlı kalmış olup, herhangi bir şekilde taklide düşmemişlerdir. Onların din anlayışı farklı ekol müntesiplerinin özgür olmadığı gibi değildir. Onların dini bu anlamda Allah'ın kitabı ve Peygamber'in Sünnet'inde işaret edildiği gibi, onunla uyum içerisindedir. Hiç şüphesiz Mısır ve Suriye'den de çok sayıda âlim gelmiştir ancak onlar Yemen Zeydileri ile kıyaslanamazlar. Allah'ın ve elçisinin bildirdiklerini anlayamayanlar, taklitten kurtulamazlar. Yemen onun düşüncesinde bağımsız âlim ve müctehidlere sahip olup asla taklide düşmemiştir. Şevkânînin aynı zamanda aşııı Şiî dogmaları eleştirdiği de bilinmektedir. Mesela Peygamber ashâbına atılan iftiraları şiddetle eleştirmektedir. Diğer taraftan Şiî kanadın bir kısmını oluşturan aşırı Şiî (gulat) dediğimiz Rafızileri de eleştirmektedir. Şevkânî'ye göre mezhepleşme, ictihâdın ertelenmesi ve taklidin üretilmesiyle ortaya çıkmakta olup bir müddet sonra da taassup şeklinde tezahür etmektedir. İctihâd kapısının kapandığını belirtmek, yaşayan Müslümanların Kitap ve Sünnet'i anlayamadıkları, zamanlarına göre uyarlayamadıkları anlamına gelmektedir (s. 145-149).

Müellif bir diğer alt başlıkta, zamanının ideal entelektüel prototiplerini Şevkânî muvacehesinden ele almıştır. Şevkânî'ye göre İbn Hazm'dan sonra İbn Teymiyye'nin kalibresinde herhangi biri bulunmamaktadır. Bu sözleriyle Şevkânî, Ortaçağ İslâm'ının ideal âlim tipini göstermiştir. İbn Hazm, mezhepleşmenin getirdiği taassuptan uzak bir biçimde hizmetler yapmıştır. Kaldı ki, onun mensup olduğu Zâhirîler, metin taraftarı/aşığı kimselerdi. Bu durum, Şevkânî'nin sürekli takdir ettiği bir olgudur. İbn Teymiyye ise, Hanbelî ekolüne mensup olarak çalışmalarına devam etmiştir. Onun düşünceleri de oldukça bağımsız ve orijinaldir. Şevkânî açısından İbn Teymiyye'nin esas önemi, politik mücadelesidir. İbn Mahluf adındaki Mâlikîâlim ise, İbn Teymiye'nin saçının telinin dahi değerinin olmadığını söylemiştir. Ancak Şevkânî bu duruma çok kızmış olacak ki, Mâlikîlerin Kahire gibi bir bölgede, en ufak meselelerde dahi Müslümanların kanını dökecek kadar aşağılık olduklarını söylemiştir. Onlar cahilliklerinden, pek çok şeyi yanlış anladıklarından, Müslüman âlimlerin kanlarını dökmekten geri durmazlar (s. 158-159). Diğer taraftan Şevkânî, el-Hasan ibn Ahmed el-Celâl (ö.1084) adındaki âlime de hayrandır. El-Celal'e sempati duymasının en önemli nedeni, insanların fikirleri üzerinde fıkhî delillere öncelik vermesinden ileri geliyordu. Bir diğer Yemen'liâlim ise Salih ibn Mehdi el-Makbeli (ö.1108) idi. Onun da takdire değer biri olmasının nedeni, bilgiye olan yaklaşımından kaynaklanıyordu. Onun hakkında şöyle diyordu: "Fıkhî delillerle uyum içerisinde olup asla taklide düşmezdi" (s. 162). Dallal'ın ele aldığı şekliyle, örnek olarak gösterilen âlimlerin ortak özelliği taklide kapılmamalarıydı. Ancak buradan doğabilecek bir yanlış anlaşılmanın önüne geçilmesi gerekmektedir. Yazarın her defasında bahsettiği taklit, sadece sonraki âlimlerin öncekini tasdik etmesi anlamında değil, bunun yanında fıkhî delillere uymak, zamanın ve şartların gerektirdiği şekilde ictihâd yapabilmek anlamına geliyordu.

Müellifin İlgisiz Entelektüeller ve Avamlar alt başığı altında sunduğu bölümde Şevkânî ekseninde, entelektüel ve avamların pasifize olmuş yönleri ele alınmaktadır. Şevkânî hizmet ettiği politik otoritelerden kendini soyutlamaya çalıştığı gibi avamlardan da soyutlamaya çalışmıştır. Öncelikle farkını gösterebilmek için zenginliğini ve elbiselerinin intişamını ortaya sermiştir. Çünkü cahil kesimin içeriğe odaklanmak yerine görünen şeylere dikkat kesildiklerini çok iyi bilmektedir. 
Ona göre taklit ilminin bu denli yaygın olmasının sebebi, bu avam denilen insanların algı ve anlayışlarından ileri gelmektedir. İdarecilerin niçin meşruiyeti sağlama noktasında âlimleri yanlarına çekmeye çalıştıkları da buradan anlaşıımaktadır (s. 175). Çünkü âlim diye lanse edilen insanların ne düşündüğünün bir hükmü yoktur. Asıl önemli olan, otorite ya da iktidar makamının teklif ettiklerini ne derece tasdik ettikleridir. Çünkü iktidar makamının öne sürdüklerini ulemanın kabul etmesi bir anlamda meşru dayanak anlamına gelmektedir. Bu anlamda Şevkânî̀ye göre hükümdarlar, âlimler ve avamlar tarafından hakikât ve adalet baltalanmaktadır. Bu âlim tipleri makam mevki elde edebilmek için bilgilerini kullanırlar. Diğer âlimler ise salt bilgi için çalışırlar. Bilgi onların hizmetçisi değil adeta efendisidir. Şevkânî'nin esas kaygısı, bilginin bağımsız hale getirilmesidir. Bir tacirin kâr elde etmeye çalıştığı araç gibi olmasını şiddetle eleştirmiştir. Dolayısıyla da ister Sünni ister Zeydi olsun tüzel mezheplerin, onların yardımıyla kurulan otoritelerin reddedilmesi gerekmektedir. Kendisinden önceki Yemen'liâlimler gibi Şevkânî de ictihâdın sadece Zeydi imamların ya da dört Sünni mezhebin icmasının elinde olmadığını belirtmiştir. Şayet böyle bir anlayış doğruysa, o zaman Allah kullarına hakikati anlayacak, kendi emirlerini hakkıyla idrak edebilecek bir anlayış vermemiş olurdu. Taklit, değişik ekollerin doktrinleriyle feshedilen bir anlayış kodları anlamına gelmektedir. Onlar inkâr etseler de kurmuş oldukları ve taklide kapıldıkları bütün ekoller sanki yeni bir dinmiş gibidir. Toplum üzerinde entelektüel otoritelerini sürdürmek için tüzel/şirket ekollerinin istek ve arzuları içerisinde hareket ederler (s. 184).

Müellif beşinci ve son bölümde ise kutsalın nasıl insanîleştirileceğini tartışmıştır. Ahmad Dallal,bu kimliklerin en ayırt edici yönlerinden biri olarak, doğaüstü bir kurguya sahip olup, madde ve fizik düzleminden uzak âlem anlayışına işaret etmekte ve bu anlayışın dönemin entelektüelleri tarafından ciddi anlamda tenkit edildiğini belirtmiştir. Ortak olan özelliklerine baktığımızda ise bu dönemde reformistlerin dikkat çektiği en önemli husus, İslâm kaynakları dışındaki kaynaklara dayanıldığıydı. Yine İslâm dışı entelektüel eğilimlere odaklanılıyordu. Reformistler sıklıkla bu anlayışları ifade etmişlerdir. Bu reformistler kendi gelenek ve tecrübelerinde müthiş bir gücün olduğunu belirterek, esas güç ve diriliş kaynağını, mensup oldukları din olarak gördüler (s. 186). Müellifin burada 18.yy düşünce ve akımlarının oldukça üstünde, doğrudan insanı ve entelektüel geleneği merkeze alan bir yaklaşa odaklandığı görülmektedir.

Her şeyden evvel bu dönemde geleneksel bilgi anlayışları ve geleneksel entelektüel normların reforma uğraması gerekiyordu. Eleştirilerin temelinde hadis ve fıkıh usûlü yer alıyordu. Diğer taraftan bütün Müslümanların en temel problemi, önceki mezheplere katı ya da körü körüne bağlanılmasıydı. Diğer taraftan 18.yy reformistlerinin zihninde hadis öğretimi, bölgesel olarak değişken ve bölgesel intiyaçlara göre şekillenen bir dizgeler bütünü olarak algılanıyordu. 18.yyreformistleri işte bu nedenle hadis çalışmalarını tekrar gözden geçirip bunun sadece nasıl geliştiğini, iç mantığı ve yapısal tutarlığını, tarihsel sürecini değerlendirdiler. Farklı bölgelerde hadislerin nasıl öğretildiği mevzusu daha çok mensubiyet/taassup duygusuyla iç içe olduğundan bununla hiç alakadar olmadılar (s. 187).

Buhari ve Müslim'in sahih çalışmalarını Yemen'li âlimler tartışmışlardır. Kur'an'dan sonra en önemli/otoriter kaynak olup olmadıklarını ve makul İslâm'ın onlar olmadan öğrenilip öğrenilemeyeceğini tartışmışlardır. İbnü'l-Vezir, Şan'ani ve Şevkânî'ye göre hadis öğrenmek son derece önemliydi. Bu isimler inceledikleri hadislerde Muaviye'nin naklettiklerine dikkatle bakıp onlarda dahi yanlış bulamamışlardır. Yani Ali'yi rencide edecek herhangi bir tutum, davranış ya da söz bulamamışlardır. Bu nedenle sahihlerin güvenilirliğinde kuşku yoktur. Buradan anlaşıldığı üzere Yemen'li âlimler, tek tipleştirilmiş, bağlamdan koparılmış hadisler yerine, evrensel, herkes için aynı olan hadis usûlü ile ilgilenmişlerdir. Şevkânî, Sıffin ve Cemel'de savaşan tarafları tekfir etmemiştir. Öldüren ve ölenleri, dünya serveti kazanmak için değil, sadece kamusal düzeni 
sağlama noktasında savaşan taraflar olarak görmüş, bu nedenle de onların her ikisinin savaşını meşru olarak değerlendirmiştir (s. 201-202).

Diğer taraftan hadis anlayışları konusunda Yemen'li âlimler delile önem verirler. Kutsallaşmış şeylerden ziyade insanîleştirilmiş şeyleri göz önünde bulundururlar. Yemen'li reformistlerden Hasan ibn Ahmed el-Celâl (ö.1673) (Yusuf 12:103) "pek çoğu inanmaz" ayetini şöyle anlamıştır: Hadis naklederken bir delil bulana dek onun doğruluğundan kuşku duyarlar." Bu doğrultuda hadis mevzusuna eğilen Şan'ani, ümmetin yetmiş fırkaya ayrılacağı şeklindeki hadisi farklı değerlendirmiştir. Ona göre burada kınanan bir grup vardır ve onlar nedeniyle ümmet ayrılık yaşayacaktır mânâsı bulunmaktadır. Yoksa ebedi olarak, kıyamete kadar ümmetin ayrı kalacağı şeklinde bir kanıya kapılmak doğru değildir. Öyle ki böyle bir anlayış ümmette determinist anlamda kaderciliğin yaygınlaşmasından başka bir şeye yaramayacaktır. Fırka-i naciye konusunda ise herhangi bir ekole ait olanlar yani Eş'ariler, Mutezilîler gibi olmayıp, Müslüman olan herkesin bu gruba dahil olabileceğini belirtmiştir. Yani Hz. Peygamber ile onun ashâbına ittibâ eden herkesin, bu kurtarılan fırka dâhilinde olacağını söylemiştir (s. 204-206).Dolayısıyla müellifin burada dolaylı olarak fırka-i nâciye konusunda sadece buna dâhil olanların Sünniler olduğu şeklindeki algıya eleştiri getirdiği görülmektedir.

Müellife göre sahihlere ittibâ etmek, taklit etmek anlamına gelmez. Sahih eserler aracılığıyla bir geleneğin yaşam biçimi diri tutulur. Burada onların fikirlerine değil, yaşam biçimlerine odaklanılır. İttibâ ile taklit arasında ayrım olduğu gibi, amel bi'r-rivayet ile amel bi'ddelil arasında da ayrımlar vardır. Burada esas meselemiz, hadislerin hususi olarak nasıl bir hayat anlayışı sunduğunu konjonktürel bağlamlarda düşünülmesi ya da hayata sokulması gerektiğidir (s.232).

18.yy reformistlerinin nazarında hadis çalışmaları söylevi, sadece toplumu yönlendirme ve Müslümanlar arasında ahlaki bir uyum/ideal yaratmak değil, daha ziyade entelektüel otoritenin miras alınan standartlarını sorgulamak ve yeniden yapılandırmak anlamına geliyordu. Hadis ve fıkıh her şeyden önce usûl zemininde değerlendiriliyordu. Öğreti haline getirilen kalıplaşmış her türlü düşünce ve inanıştan kurtulmanın gerektiği önemle vurgulanıyordu. Hadislerin günümüze göre uyarlanmayıp bağlamı dahilinde düşünülmesi, daha doğrusu mevcut zamana uyarlanmaması, ictihâda gidilmemesi büyük bir problemdir. Bu sebeple isnat büyük bir zarara neden olabilmektedir. Bir sözün ya da geleneğin doğruluğu ya da yanlışlığına dikkat kesilip o hadisin nasıl uyarlanacağı ya da usûle ne derece uygun olup olmadığı gözardı edilmektedir. Bu nedenle de ciddi zararı söz konusudur. Bir kere bu anlayışta ısrarcı olmak, mevcudun otoritesini yok eder. Müslümanların yaşayan toplumunu adeta bu salt bilginin üreticisi ve sahibi haline getirir. Bu sahiplenme, taassuba dönüştüğünde ise üretildiği bağlam dışına çıkıp modern zamana göre çağdaş bir biçimde uyarlanamaz. Bu sebepten de taklit, ictihâda galip gelir (s. 234). 